\title{
WALSH VUELVE. NOTAS SOBRE UNA ESCRITURA QUE NO SE APAGA
}

Sobre Jozami, Eduardo ... [et al.]. Walsh en presente. Buenos Aires, Indómita Luz. 2017. 116 pp.

María Agustina Catalano

Universidad Nacional de Mar del Plata

Universidad Nacional de La Plata

Rodolfo Walsh vuelve. Sigue interrogando nuestra situación actual y, por qué no, iluminando algún lugar del futuro. Su escritura es una luminiscencia o un fuego que todavía no se apaga. Walsh en presente es una prueba de eso.

Este libro, editado el año pasado, se enmarca dentro de una constelación de publicaciones e intervenciones recientes que, una vez más, pusieron a Walsh en el centro de la escena. Habrán sido las efemérides celebradas (40 años de su desaparición-asesinato, los 60 de la primera edición de Operación masacre o 90 de su nacimiento) o la necesidad de buscar en la potencia de esa voz, alguna evidencia para entender nuestro presente; la cuestión es que Walsh vuelve. En forma de libro, de muestra fotográfica o de jornadas de debate, está de nuevo interpelándonos. ${ }^{1}$

\footnotetext{
${ }^{1}$ En 2017 se celebraron las "Jornadas Nacional de Homenaje a Rodolfo Walsh" en la Universidad Nacional de Mar del Plata, durante el mes de marzo, y más tarde las "Jornadas Rodolfo Walsh", en la Biblioteca Nacional de Buenos Aires. También las muestras fotográficas "Rodolfo Jorge Walsh: El guerrillero" y "De resistencias y compromisos", en la Casa Rodolfo Walsh ubicada en el barrio porteño de Palermo. Este año, se publicó Cicatrices sobre un mapa (UNMdP), libro que compila los trabajos presentados en aquellas primeras jornadas marplatenses, Oración. Carta a Vicki y otras
} 
Walsh en presente es una publicación colectiva, la primera de la joven editorial Indómita Luz, que a su vez integra la Confederación de Trabajadores de la Economía Popular (CTEP). ${ }^{2}$ Sus páginas refuerzan la idea de que todavía hay trabajos de Walsh que merecen ser leídos con detenimiento, al mismo tiempo en que actualizan las miradas y versiones que de él tenemos. El texto nos lleva a leer el Walsh que conocemos, al que siempre regresamos, el militante, el periodista, el escritor, pero sin dejar de leer ahí, en esas imágenes algo cristalizadas, contradicciones, líneas de fuga, hendiduras. Por otra parte, el prólogo de Iciar Recalde afirma que no es azarosa la elección de Walsh para iniciar un proyecto editorial de estas características y, sobre todo, en este contexto socio-histórico. $\mathrm{Su}$ nombre resulta fundamental a la hora de pensar en un espacio que "sin lugar a dudas, promoverá la publicación de voces negadas por el monopolio de las grandes editoriales" ( $p$. 15).

El volumen abre con una entrevista a Eduardo Jozami (escritor, periodista y autor de varias publicaciones sobre Walsh), que reconstruye de alguna manera su itinerario o trayectoria intelectual y política, desde su breve paso por la Alianza Libertadora Nacionalista, hasta la posibilidad de un "legado walshiano" (p. 28). Después vienen los artículos, organizados en dos secciones ("Leer a Walsh" y "Walsh: presente y futuro"), que se ocupan de distintos problemas y obras. El primero de ellos, "Rodolfo Walsh, cronista de los olvidados", de Rodolfo Edwards, rescata dos crónicas publicadas en la revista Panorama en 1966, "La isla de los resucitados" y "Carnaval café", donde aparece el Walsh que

elegias políticas, de María Moreno y Rodolfo Walsh, reportero en Chile. 1970-1971, que reúne sus crónicas escritas durante los días de Salvador Allende.

${ }^{2}$ Ver https://www.facebook.com/indomitaluzeditorial// 
pone el ojo en los rezagados del sistema, pero también otro Walsh, "el montajista", que muestra una "sinfonía terrorífica" (pp. 35-36), con la pluma cargada de palabras lacerantes y exquisitas. En "Rodolfo Walsh: un periodista de acción", Marcela Repossi construye un collage de tópicos y problemáticas que atraviesan toda su obra, en sentido cronológico.

Mario Goloboff, en "Dos ensayos breves", reconstruye el universo de lecturas de las décadas del cuarenta y cincuenta, que sonarán, con mayor o menor fuerza, en la escritura walshiana. En este texto, nos encontramos con el ávido y perspicaz lector que fue Walsh y, además, con el editor, el traductor y el crítico. Goloboff menciona cuatro notas en las que estas facetas pueden apreciarse: " $i$ Vuelve Sherlock Holmes!” (1953), "Dos mil quinientos años de literatura policial" (1954), "El genio del anónimo" y "Un estremecimiento, por favor" (1954-1955). Y cierra diciendo que de las muchas enseñanzas que Walsh nos dejó, le interesa rescatar una: "hay muchos caminos para llegar al conocimiento y a la defensa de las más nobles causas humanas. El de la frecuentación de la gran literatura es uno de ellos, y no el peor" (p. 52). En su otro apartado, se preguntará qué ha hecho a la grandeza de "Esa mujer".

"Ese hombre, sin muerte" de Diego Ardiles (compilador del libro), nos lleva, a través de una canción de Silvio Rodríguez, al último día en la vida de Walsh. Una vez situados en esas fatales horas, viajamos al presente, para analizar las "ondas expansivas" (p. 58) de ese hecho (su desaparición y muerte) que llegan hoy hasta nosotros. El trabajo de Ardiles nos interroga: ¿qué hicimos con Walsh?, ¿dónde lo pusimos?, ¿cómo pintamos su retrato? A continuación, Paula Tomassoni, en "Puesta en escena como palabra pública: Walsh y el género espectacular", elige otras dos preguntas para hablar de Walsh: 
¿sobre qué escribir y para quiénes? A partir de ellas, observará los movimientos del escritor como parte de una puesta teatral, de un diálogo entre espectáculo y espectadores, y retomará sus dos piezas La batalla y La granada y la experiencia de Operación masacre en el cine. Por último, Diego Igal se enfocará en "Todos los misterios de la Carta de Walsh" y nos dará precisiones y datos, quizás desconocidos para muchos, sobre el derrotero de su último escrito. Con el ritmo obsesivo de un reportero que sigue el minuto a minuto de un partido, Igal consigue transportar al lector a ese momento histórico clave y a la vez algo enigmático.

En el segundo y último segmento, Sebastián Hernáiz y Natalia Vinelli buscan las huellas de Walsh en la actualidad. Hernáiz, en "A 40 años de la Carta Abierta de Rodolfo Walsh", asegura que "leída de nuevo, desde la Argentina sometida a los vaivenes macristas, la descripción del proyecto económico de la dictadura se actualiza dramáticamente y obliga también a preguntarse por el presente de esa frase que subrayábamos", refiriéndose a unas líneas de la carta, que dicen: "Congelando salarios a culatazos mientras los precios suben en las puntas de las bayonetas" (p. 100). ¿Cuáles son las bayonetas y culetazos de hoy?, se pregunta. Y, por otro lado, Vinelli enumera "Siete propuestas sobre periodismo, militancia y revolución inspiradas en Rodolfo Walsh", de algún modo, como respuesta a la pregunta inicial acerca de la existencia de una herencia walshiana. Así pone el punto final, diciendo que Walsh "nos interpela sobre el tema espinoso de la verdad en un contexto de cerco mediático" (p. 110). Ardiles refuerza esta idea en una entrevista para La pulseada, reconociendo que todavía tiene mucho para decirnos "en términos coyunturales". ${ }^{3}$ El libro no pretende clausurar este vínculo

${ }^{3}$ Ver "Ese hombre: Walsh en presente". Entrevista a Diego Ardiles por Josefina Oliva. Disponible en http://www.lapulseada.com.ar/ese-hombre-walsh-en-presente/ 
entre Walsh y la coyuntura actual. Al contrario, los interrogantes quedan flotando en el aire, dispersos entre nosotros. En definitiva, Walsh es una referencia ineludible al momento de reflexionar sobre nuestro tiempo. Ya sea porque nuestro tiempo no es tan diferente ni tan distante del tiempo que le tocó vivir a él, como a veces creemos. Ya sea porque supo señalar y decir, quizás como ningún otro, las miserias e injusticias que nos oprimen. O porque la fuerza y la vitalidad de sus acciones nos empujan a resistir, en días en los que es urgente hacerlo. 